Narotzky, S. (2018) "Rethinking the concept of labour", Special Issue on Labour, Penny Harvey and Christian Krohn-Hansen (eds), Journal of the Royal Anthropological Institute, Vol.24 (S1):29-43

\title{
Rethinking the concept of labour
}

\author{
Susana Narotzky University of Barcelona
}

Is labour a useful concept for anthropology today? This essay attempts to respond theoretically to the challenge that the contributions to this special issue empirically pose. The essay rethinks the concept of labour by addressing three questions that deal with the relation of human work effort and capital accumulation: the first refers to alienation; the second to the difference between abstract and concrete labour; and the third to ambiguity. Over the years, these issues have addressed particular aspects of social reproduction, helping define labour as a concept, albeit a heterogeneous one,that is relationally linked to capital. Dislocation, together with the parallel concepts of dispossession, disorganization, disconnection, and differentiation, emerges prominently in the analyses of contemporary labour transformations and spacificities. Finally, the essay engages with seemingly disappearing labour futures and what this means for the concept of labour. What is the value of work for capital and, conversely, the value of labouring for people today?

\section{Introduction: a problem of method}

This special issue on labour raises important questions that we will probably not be able to resolve but which should not be hastily dismissed. First, there is the epistemological question of the value of concepts cross-culturally and cross-historically, in this case the value of the concept of 'labour'. Anthropologists (but also historians) have been struggling with this thorny issue from the outset. How useful is an extraneous concept to understand the processes, conflicts, settlements, tensions, and harmonies that take place in a historically and culturally different environment where our present-day Western categorizations may not exist, or may be embedded in a very different reality? As many have argued, the nature/culture divide or the self-contained individual may not be significat, whereas other unknown forms of categorization may be present that we cannot fathom or imagine. In sum, this epistemological question determines our method and the internal tension that makes its value. If we abandon the quest for universally applicable concepts, we are at pains to justify the worth of our discipline for we cannot compare, and the terrifying 'so what?' dilemma emerges as we become cornered into being mere consumers of native theory. If we do not acknowledge the concreteness of living experience and its eventual incommensurability, on the 
other hand, we may fail the quest for ethnographic understanding. Understanding the world and its diverse inhabitants in their own terms, their specific connections and disconnections, dissolves distance. Yet modernist epistemology requires a separation between subject and object and the creation of some fictional building blocks (concepts) which are thinking tools: that is, they do not describe reality; they attempt to explain it by producing abstract paths, logics, articulations (cf. I.akoff \& Johnson 1980 on the Western building metaphor of scientific arguments). Hence, do we need a concept at all if every cultural understanding of life-sustaining practices is not only different but also part of a way of being in the world and becoming a concrete and unique entity? Can a concept such as labour bridge the gap between the inescapable concreteness of lived experience and the diverse abstractions used to make sense of it? Can it be useful as a tool for explaining what goes on in different parts of the world regarding the forms in which energy is expended, co-ordinated, and organized in order to sustain life and make it worth living? If we think of the world as connected, it makes methodological sense; if we think of the world as an aggregate of multiple worlds, it may make little sense.

So there is a preliminary decision that refers to method. Anthropologists have been stressing the connection between the world's inhabitants (human and nonhuman) in the era of colonial expansion and later globalization. Therefore, movements and logics are also historically connected, dependent phenomena rather than independent materializations (manifestations). Moreover, capitalism, or the 'self-expansion of the money form of value' (Elson 1979: 165), has been deployed in most places, although with its particular forms of embeddedness, translation, and interpretation which are tied to historically uneven and combined developments, and sociocultural imperatives (Allinson \& Anievas 2009; Rosenberg 2006). As feminist economists, anthropologists, and critical social scientists in general have pointed out frequently, this form of value and the relations it entails do not saturate the social space. What is probably even more significant, they are not separated from other forms of value and relationships, nor do they function in another realm. In fact, it would seem that the way in which these other relations and values appear is central to how capitalist relations develop and enable the 'self-expansion of the money form of value' to take hold. Capitalist relations are always parasitical on ongoing relational connections that guide worthy life sustaining practices.

Harvey and Krohn-Hansen in the introduction to this issue define their aim as

exploring the tension between the ways that global capitalism might connect the experience oflabour on the assembly lines of the Chinese factory to the experiences of those engaged in the mining of coltan or working in the container shipping industrywhile at the same time not connecting them at all, not simply fragmenting but also necessarily responding to hugely varied histories and fields of expectation (emphasis added)

At the same time, the issue attempts to investigate 'dislocation in which places and persons are reconfigured by movements of capital' (p. ???). It remains to be seen if the connected-disconnected-dislocation triad the authors of this issue are exploring rests on labour as a concept rather than labour as a description of local experiences in a world dominated by global capitalism. The introduction, in a clear support of labour's conceptual strength, points out that 'a focus on labour, in this second decade of the twenty-first century, configures a field of ethnographic concern that conjures both the systemic force of capital, and the historical specificity ofhow these ever-shifting capital relations play out in practice across the world' (p. ???). Theoretically exploring this assertion is the objective of this essay. 


\section{Historicizing labour}

The history of the concept of labour in Western thought shows how its development was tied to productive tasks (in particular agriculture) and drudgery. In late medieval times, an idea of a 'common good' objective in the motivation of work transforms the originally servile substance of the concept into a vocational one which refers to the divinely preordained tasks of one of the three orders of society (oratores, bellatores, laboratores). It describes status adscription rather than a property of the individual (Duby 1980; Le Goff 1980). In its development as a concept, three processes become salient: (1) the shift of productive effort from a derogatory to a positive status in the late Middle Ages; (2) the idea that it expresses the participation in a collective (social) process aiming at the common good; and finally (3), with the coming of modernity, the individualization of the human productive relation to nature (Castel2013; Locke 1986 [1689]). These three aspects - productivist, social, and individual-become entangled in the concept that political economists inherit and that in turn Marx will develop as the cornerstone of his theoretical construct. As a consequence, the dominant concept of labour rests on an idea of society or a collective good, an idea of individually selfcontained creative energy, and an idea of the objectification of energy in material production. These elements are present in the labour theory of value and in the triad of aspects that support it, namely the concrete, social, and abstract forms of labour.

In addition, as a social science concept, labour is generally paired with capital and referred to historical contexts where work is somehow connected with the process of capital accumulation. Beyond the understanding of labour as a wage relationship with the owners of the means of production that enables workers to make a living, many forms of relations have been explored that connect unwaged work (communal, unpaid, volunteer, affective, unregulated tasks) and even non-work (unemployment, leisure, idleness) with capitalist accumulation processes. This extension of the concept of labour still preserves as its core meaning the multiple forms of its relation to capital.

In the last fifty years at least, the concept has suffered extremely pertinent and creative critiques, mostly by feminist scholars who have introduced reproductive work into the conceptual realm of labour, pointing to the centrality of its particularities (e.g. emotional and relational value) for the social reproduction of a labour force (Dalla Costa \& James 1972; Hochschild 2003 [1983]; Lawson 2007; Nelson 2006). Anthropologists as well have provided important critical perspectives that show the cultural and historical embeddedness of life-sustaining practices and question the universal applicability of the Western concept of labour to make sense of the diversity of human livelihood practices (Escobar 2008; Gudeman \& Rivera 1990; Malinowski 1978 [1935] Strathern 1988).

So where does this leave us? We are confronted with a need to rethink the concept of labour or else abandon it, not least because the actual practices that supported the original development of the Western concept have been transformed while the connectivity of life-sustaining practices has expanded globally. This is the task that this special issue provocatively proposes. Is a concept of labour useful? How is it useful? And what concept should that be?

\section{Work and labour}

English-speaking scholars have often been using a distinction between 'work' and 'labour', where labour is defined as human effort which pertains to capitalist relations of production, and work describes the rest of human energy expenditure in relation to non-capitalist realms, whether these be reproductive tasks (which eventually became 
(generally but not solely productive) in the margins and interstices of the capitalist market system or in non-capitalist historical or present-day societies. However, this distinction cannot be drawn in other languages (e.g. Spanish or French) where there is a common word for work and labour, and, conversely, other languages have various significant categories to describe creative effort (Frayssé 2014). While this might be taken as a hindrance to the development of a clear concept of labour, it also points at what anthropologists confront in the field: scientific conceptual distinctions cannot rest on a nominalist basis, although naming the world is a form of engaging with it that has practical consequences and hence must be acknowledged by those seeking to explain it.

The main problem with the work/labour conceptual distinction, in my opinion, is that it makes two presuppositions: first, that there is something inherently different between one form of effort expenditure and the other, namely the kind of value that is created; and, second, that they cannot be simultaneously present in the human experience of energy expenditure. This brings up three questions that need to be addressed in order to rethink the concept of labour: the first refers to alienation; the second to the difference between abstract and concrete labour; and the third to ambiguity.

\section{Alienation: the objectification and exploitation of labour}

The idea of alienation as defined in Marxist literature describes, on the one hand, the separation of the product of labour from the person who has produced it (this is the process of objectification) and, on the other hand, the appropriation of a person's labour and hence its product by someone not involved in its production (exploitation) (Axelos 1976; Marx 1959 [1844]). Moreover, alienation has also been understood as the separation of labour in capitalism from its concrete conditions of reproduction (what makes a life worth living), a process that Karl Polanyi (1957;1971[1944]) described as the disembedding of social relations and the production of labour as a fictitious commodity. Yet it is because productive activity is understood as the concrete self-realization of the individual worker that its estrangement through the double form of alienation becomes the critical aspect of capitalist relations.

Objectification of concrete labour has often been accepted as a universal phenomenon inasmuch as the framework of individuation and material autonomy of the product are taken for granted. Exploitation, on the other hand, has been strongly circumscribed to particular historical periods and often limited to capitalist relations, where wage-labour and commoditization of social reproduction prevail. This neat conceptual separation is difficult to sustain with the ethnographic record, not only for non-capitalist-dominated realms of social interaction and non-Western cultural environments, but even for commodity chains in contemporary capitalist production. Indeed, the conceptual attachment of creative energy to the human individual as a power producing life and providing rights through its expenditure is itself an ideological creation of particular historical interactions which are not restricted to the liberal enlightenment, as Aron Gurevich (1985) shows for medieval Iceland. Creative energy can be understood as distributed in networks that bring together human and non human entities-as Actor Network Theory proposes in present-day Western scholarship- or the individual can be but a volatile form of social interaction (Strathern 1988), and objectification may occur partially, if at all (as with artisan artistic branding of oeuvres: Cant, this volume). The more general critique is that even in a context dominated 
by capitalist relations, human labour is never fully disembedded. In fact, by following supply commodity chains, we can observe that the alienable aspect of labour, what makes it exploitable in a particular way, always depends on its inalienable ties to the social environment. Hence when we observe the concrete life projects of people as they unfold in different parts of the world, and how they are woven into particular forms of surplus extraction or appropriation, we immediately realize how important relations such as kinship obligations and claims are to the setting of localized forms of capitalism. I would argue, nevertheless, that there is a logic to the way surplus extraction operates at different scales, and it is not merely contingent on emergent and unpredictable forms. Two complementary processes are always at work in capitalist accumulation: rent extraction (through land rent, financial fees, patent rights, etc.) and surplus value extraction (through exchange relations, contractual agreements, or predatory domination). The first rests on privileged rights of access, the second on reduction of the cost of labour by competitive means, crude domination or otherwise. And both rely on the entanglement of values pertaining to different realms of moral obligation (personal, intimate, social, market, contract, etc.) and on the tensions and overlaps between the concrete and abstract value of labour.

\section{Concrete and abstract labour: a reassessment}

Much of the anthropological unease with the Marxian labour theory of value stems from its development of a dual aspect oflabour, namely the distinction between the concrete and abstract labour embodied in the commodity. Concrete labour has been defined as the energy, embodied skills, cultural beliefs, and forms of co-operation expended to create a specific product (or service). Abstract labour has been usually understood as related to the existence of a developed market exchange system that would theoretically

pool all socially necessary labour (i.e. the labour needed to reproduce a society) and hence enable the evaluation of the proportional quantity of social labour embodied in a particular item. Following this, concrete labour could become a universally applicable concept, whereas abstract labour was circumscribed to societies (and sectors of production) where capitalism was hegemonic. This questioned the core of the labour theory of value and became one of the major challenges among Marxist feminists when trying to think about the value of domestic labour and its possible exploitation in relation to systemic capital accumulation processes. The same problem assailed anthropologists studying small family production and subsistence work in agriculture all over the world, and sociologists looking at self-provisioning practices (Pahl1985). Those studying societies (or activities) hypothetically isolated from capitalist forms of market exchange had no direct use for the theoretical duality in Marxian value theory. However, Diane Elson (1979: 144, also 148), in a clarification of Marx's 'value theory of labour', proposes that the four aspects (concrete/abstract and private/social) of labour are present in all societies, and, according to Marx, what differs is the social form in which they appear: 'What is specific to a particular kind of society is the relation of these aspects to one another and the way they are represented in the precipitate forms' (1979: 149). In particular, abstract labour is not limited to societies where market exchange prevails in social reproduction. The abstraction refers to a quantitative proportion of the human energy and time necessary to reproduce the social totality as a meaningful whole, and this whole encompasses any collective effort in whatever form it is co-ordinated (i.e. not necessarily through market co-ordination). Elson adds that 'the objectification of the concrete aspect of labour is universal [in the concrete object or service], but 
the objectification of the abstract aspect of labour [in money] is not: it is specific to capitalist social relations' (1979: 150). What is elusive in non-capitalist societies is the representation of this abstraction in a particular physical form (i.e. a unique universal equivalent, money) (1979: 164-5). That is, in the labour concept, the aspect of abstract labour exists in all historical societies but its objectification, its materialization in an object, does not. This, then, would be the main specificity of societies where capitalism is dominant: the fact that in the value of commodities the objectified abstract aspect of labour (money) reflects value which 'produces the illusory appearance that value in its money form is an independent entity' (1979: 165, original emphasis). Abstract labour in its objectified form, then, subsumes (but does not obliterate) the other aspects of labour and becomes the hegemonic driver of production. Making money instead of making useful objects.

This reading of Marx's theory renders his multidimensional concept of labour more useful to anthropologists because, on the one hand, it opens the field of possible forms of objectification of the abstract value of labour to whatever is the dominant universal value equivalent present in a particular society (e.g. kinship, prestige, etc.). The concept can also be extended to include the entanglement of dominant and non-dominant value realms of society, and of activities that are sustained by ambiguous claims to labour, as when unwaged kin working in a family farm produce food within a global commodity chain (Martin, this volume; Melhuus, this volume; Narotzky 2016). On the other hand, it refocuses the Marxist question on labour instead of value. Indeed, the 'value theory of labour' is not the 'labour theory of value'. Labour-that is, human life expenditure in order to reproduce life-is at the centre of Marx's theory, a preoccupation that began as an inquiry placing 'real life' and 'practice' as the starting-point (Marx 1969 [1845]). From this perspective, labour and life are two sides of the same coin and their entanglement is universal (see Collins 2016 for a reassessment of the labour theory of value taking these issues into account). Of course, some conceptual problems remain, in particular the individualization of human energy and its creative power, although it is always presented as attached to the collective and relational objective of social reproduction, which constitutes, in fact, the argument for the existence of abstract labour.

Hence, the concrete and abstract aspects of labour cannot be separated. They are intimately co-dependent and transform each other simultaneously. In addition both, even in Marx's original theory, are social and relational processes whose form is contingent on historical and spatial unfolding. In sum, we should ask ourselves what kínds of labour are mobilized to reproduce a society and, in a context of dominance of the capitalist form of value expansion, what aspects of concrete historical and sociocultural contexts are encroached upon, co-opted, or transformed by capitalist relations in the process of global accumulation. This volume's contributions present enlightening cases of how these developments can occur.

\section{Ambiguities of labour and capital}

The essays in this volume underline the different ways in which labour is connected with capital. Very central to this is the stress on the concrete aspect of labour with the embodied experience that it supposes and the placeness of the relationships in which this experience can occur. In each place, difference becomes the paramount value that capital puts to work. Yet we must beware of considering capital as a homogeneous and a-temporal force that impacts or transforms some traditional labour relations. Conceptually, capital and labour are forces co-emergent at different scales, 
simultaneously local and global and constrained by other forces and their agents, such as those making the state or driving the actions of various power-holders. As the concrete aspect of labour gives form to the manner in which abstract labour is configured, the reverse also holds: there is a concrete aspect of capital, of the way in which concrete agents create capital as a particular relation with labour in one or multiple locations (Bourdieu's social, symbolic, and cultural capitals, attempt to capture this diversity for the French context). Perhaps Sylvia Yanagisako's essay in this volume is an extremely clear example of this, but it is present in all the pieces, because labour and capital, as concepts, exist only as a relationship, which is concrete and place-bound (i.e. different) while it simultaneously is abstract and hence distributed across the globe in its objective of expanding the money form of value (i.e. equivalent). As a result, the relational forms of these historical precipitates of concrete and abstract aspects are dynamic, even if, conceptually, what defines that relationship is the self-expansion of the money form of value and the subsumption of other forms of value to this objective.

As anthropologists, we are driven to the concrete expressions of the labour/capital relation out of necessity, as this is the experience that the ethnographic method provides us with and becomes the basis on which theory is developed. Indeed, when we observe labour forms, we tend to set off from their embedded character: the way that kinship, cultural understandings, and historical factors are central to the way people engage productively with local and global forms of capital. Keir Martin, in this volume, illustrates this embeddedness in an apparently paradoxical manner when he points at how the local use of the labour category (here defined as wage-labour) defines a particular relationship to land and labour that is not tied to 'custom' ('kastom'). Instead it attempts to assert private property over land, turning it into a small commodity production factor in the wider context of agriculturalcontract farming (see also Li 2014 and Moberg 2014 for similar examples). What seems to emerge in this ethnographic account is the scope for interpretation that kin-related persons' work on a piece of land may hold. We are presented with the struggles around the attempt by different actors to circumscribe the work's worth and the value realm to which it pertains either in capitalist exchange or in custom. Conflicting processes of distinction and of blurring of the categories describing activities as wage-work, or help, or respect become instruments for defining land ownership and access rights. Beyond the instrumental use that various categories enable, ambiguity emerges in these conceptual struggles as an expression of the fact that people try to negotiate ambivalent value domains in everyday practice (also Harvey, this volume; Hoem, this volume). The tensions between concrete and abstract aspects of labour are always present together with the simultaneous experiencing of different domains of social interaction where worth and value are not the same or even congruent. Particular forms of agency, of exploitation, of governmentality, of resistance, of struggle, result from the way in which localvalue realms overlap in the space of global capitalism. As a result, sites of labour/capital conflict shift, are blurred, and become dislocated in global capitalism.

\section{Dislocation: place and time}

In the present volume, the idea of dislocation emerges as key to the understanding of a renewed concept of labour. Dislocation refers to the spatial unevenness of capitalism's global unfolding as well as to recent upheavals in the livelihood experience of people in places. It relates to structures of feeling that are both temporally and spatially volatile, inconsistent, or violently transformed. One may argue that dislocation is not 
new in the process of capitalist expansion, nor in past historical forms of predatory conquest (Gill \& Kasmir 2016). At various moments in various places, life (human, nonhuman, environmental, and symbolic aspects of it) has appeared as dislocated by the forceful expansion of the money form of value in the case of capitalism, in a process of commodification akin to that described by Polanyi (1971[1944]) for 'fictitious commodities' (see also Burawoy 2010). Indeed, this aspect should be included in the concept of labour for it is a core defining dimension of the experience of the emergent relation between capital and labour. Dislocation, however, complements two other key aspects of the process of uneven development of capitalism as it affects labour, namely dispossession (Harvey 2003; Kasmir \& Carbonella 2008; Palmer 2014) and political disorganization oflabour (Kasmir \& Carbonella 2008:12). These three aspects together point to the relational unfolding of social relations in global capitalism: culturally embedded forms of organization are disorganized; place-bound paths of dispossession are continuously generated; and waged and unwaged forms of making a living change repeatedly and pull people apart or together at different conjunctures through space and time. All contribute to the historical dynamics of remaking differences that reconfigure labour/capital power geometries.

David Harvey (1990) theorized the process of time/space compression that linked technologies with the acceleration of the circulation of capital and, hence, accumulation (this is particularly salient in financial capitalism). In parallel, the injunction of productivity has accelerated work rhythms while compressing leisure, rest, and work time in many new forms of labour. Christian Krohn-Hansen, in this volume, presents the opposite dislocation of temporal work rhythms as the national brokerage networks, deficient infrastructures, and global competition provide an erratic base for the deployment of productive labour in the Dominican Republic. Elsewhere, the distinction between labour and personal time or productive and reproductive time (and spaces) disappears for an increasing sector of the world's population as income-generating labour invades home and leisure spaces and timeframes. The way the dislocation of time emerges is linked to local conditions of opportunity and to how people attempt to make a living in places. Displacement may appear as forced mobility, as when local populations are displaced by the opening of a mine that destroys their town but where they might have preferential job opportunities. It is often a simultaneous process of dispossession of land, of sacred sites, of ways of living. Conversely, mobility may become the only remaining form of autonomy, as when hope for the future gets tied to migration projects (Cale 2014; Glick Schiller \& Çaglar 2009; Pine 2014). Yet movement always tends to disorganize some institutional frameworks while it opens the way to new forms of organization by reconfiguring meaningful connections between people.

The processes of dislocation in capitalism interweave individual, household, and social networks of working lives with past histories of labour/capital relations as they have unfolded both locally and globally, at once limiting, opening, and defining the available opportunities to make a living and the kinds of social recognition they entail. James Ferguson has pointed our attention towards the relevance of 'structures and processes of disconnection' (2009: 316) that produce

abjected, 'redlined' spaces of decline and disinvestrnent in the contern porary global economy [ which] are as much a part of the geography of capitalism as the booming zones of enterprise and prosperity ... They refer to processes through which global capitalism constitutes its categories of social and geographical membership and privilege by constructing and maintaining a category of absolute non-membership (2009:317). 

Indeed, geographical membership and the privileges attached to it seem to be emerging as crucial sites of conflict among labour as they express the reorganization of spaces of capital and its spatial fixes and the dislocation of the livelihood systems attached to them.

Place is formed and transformed by the articulated forces of capital, labour, and the state in the longue durée, as Huw Beynon, RayHudson, and David Sadler (1994) pointed out over twenty years ago, but also by the forces of local responsibilities, meanings, and expectations that are part of the historical entanglements of the place (see Escobar 2008; Harvey, this volume). Place is the domain of concrete existing people while space often appears as an abstraction. But space, in an analogy with the abstract aspect of labour, stresses the relational value of places for social reproduction, and appears as an inseparable aspect of the concrete place. Space, on the one hand, engages with capital as an emergent abstraction of relationally located, connected, and disconnected social relations, while capital can only be realized in places, through places and their concrete social differentiations. Space expresses the power of the state (and capital) as an abstract relation of domination, although this power can only be realized in places through the concrete production and (often violent) enforcement of difference or, on the contrary, through the enforcement of homogenizing norms. Place, on the other hand, grows from the meaningful relationships that people build with each other in the long term and from their engagement and creative production of institutions in particular locations. Place is multidimensional and the primary referent of people's lives, of the everyday practice of located sociability. Often described as a local affair, however, place is also multiscalar, as social, economic, and power relationships that produce place occur at various scales (local, regional, national, global) and simultaneously transform the operational scale of political-economic processes in space (Peck 2002; see in particular the essays by Cant, Campbell, Hoem, and Schober in this volume). Concrete agents' understandings inform practices occurring at multiple scales that take into consideration the values (or value) most dear to each actor and use them to make differences. Hence differences are created as a resource to take advantage of, resist, exploit, or capitalize. Some people (within households, regions, firms, or institutions) will have a great capacity to define, impose, and benefit from particular differences between and within places (and people) while others will have a limited one. Geometries of power result from the capacity of some agents to define, enforce, and take advantage of difference both within and between places (and people) in their interest. Making difference between places is also often making difference between the past of these places and an alleged better (or worse) present or future there or elsewhere.

Much in both the concrete and abstract aspects of labour depends on the historical processes of making differences and on how they combine with each other globally at particular junctures. Spatial differentiation, then, produces topographies of value where life and work are not worth the same; it materializes and induces a process of dislocation through movement that complements other dislocations linked to the life rhythms and time/effort ratios for earning a livelihood.

\section{A labour concept for 'no labour' futures?}

Recently, anthropologists (Ferguson 2013; Li 2009; Smith 2011) have been pointing to a reality that was already debated in the 1960s and 1970s by Latin American scholars (Nun 1969; Quijano Obregón 1974 and the surplus population debate). The capitalist system seems to have no use for an increasing number of people, either as labour, consumers, or rent providers. This has been publicly acknowledged by policy makers, 
mainstream economists, and the media admitting that 'full employment' is impossible and that structural unemployment rates will grow as a consequence of technological innovation, robotization, and globalization.

Does this mark the end of a concept of labour? A look into the former debate surrounding development policies and the place of the so-called 'informal sector' in them brings some useful insights. In the 1970s and 1980s, the distinction between stable, contractual, protected, waged labour relations and insecure, precarious, often personalized work relations or self-employment ventures became the basis for describing the economy as a dichotomous structure of mutually excluding and hierarchically ordered arenas of production: the formal and the informal sectors (a distinction that development agencies such as the International Labor Organization supported and extended, see Peattie 1987). Additional observation of the endless variations of possible relations of production/reproduction that exist in global capitalism, including at its margins and in its interstices, led to an early critique of this dichotomous opposition, while the connection between formal and informal 'ways of doing' and making a living was stressed (Mingione 1991; Peattie 1980;1987; Portes \& Sassen-Koob1987). John Weeks (1971) pointed out that 'unemployment' rarely describes a permanent out-of-work situation and is often premised on a particular administrative definition of employment as contractual wage-work in the formal sector. Jan Breman's classical critique of the formal/informal sector duality in the 'third world' (1976a; 1976b; 1976c) observed that the dichotomy lost 'sight of the unity and totality of the productive system' and he emphasized instead 'the fragmented nature of the entire labour market' (1976a: 1871). In this view, the labour market is fragmented but continuous, and the social relations that constitute it in everyday practice are multiple, entangled, and result from their historical interaction.

Anthropologists, in particular, paid attention to household resources, micro-power relations, mobilities, and temporalities that structured differential access and reciprocal relations within and between households (Melhus, this volume). This perspective highlighted the diversity of jobs that household members undertook and the fluidity between stable, protected, waged work (formal), self-employment, peasant farming or small workshop ownership (partially regulated), casual jobs and unregulated selfemployment (informal), and unemployment. The ingenuity of poor households to pool and distribute all kinds of resources to 'make ends meet' was acknowledged by the 'livelihood means' and the 'resources of poverty' development literature, where this diversity was rebranded as an asset for household reproduction (Scoones 1998). Mercedes González de la Rocha (2001), however, has pointed out that, following structural adjustment policies in Mexico that eroded labour market opportunities, households were at pains to survive because waged and non-waged income resources were complementary rather than a substitutefor each other. 'A new type of labor market segmentation seems to be emerging, not along formal/informal lines but between a very privileged group of workers and the vast majority who struggle to survive with very limited resources' (González de la Rocha 2001: 90).

One of the findings of this initial assessment of the complexities of labour relations in 'third world' regions may prove particularly useful to present-day analysis of precarity in 'post-industrial' economies. This is the observation that scarcity of income-generating opportunities often results in 'the necessity to fence off one's own domain', looking for 'protection along vertical lines, the contracting of obligations in patronage and brokerage relationships with privileged kin or social superiors' (Breman 1976c: 1942; 
also 1976b: 1908). However, when (and if) the situation of generalized precariousness becomes extreme, even vertical loyalties and particularistic obligations disintegrate and personalized claims are interpreted as predatory (Breman 1976c: 1942). Thus, extreme labour market fragmentation is also a process of dispossession that generates particularistic forms of protection, even as it disorganizes collective ones (see also Kasmir \& Carbonella 2008:14-15). The loss of wage-labour is experienced as an end to life, the ultimate dispossession, as when the Korean Metal Workers' Union leader says in 2013:'There is no futurel', or when a representative during a South Korean parliamentary hearing in 2011 argues that the Hanjin Heavy Industries and Construction shipyard's chairman had 'murdered his employees with massive lay-offs' (Schober, this volume, pp. ??? and ???). Death is both a metaphor of an industrial past where labour was relevant for social reproduction and an embodied materiality in increased morbidity and suicide.

In the post-industrial era of 'mature' capitalist regions such as Europe or North America, the demise of waged work dominance recalls forms of labour differentiation, insecurity, and precariousness that were imagined as more suitable to other times or other countries. Working lives are pushed outside of the relatively secure incomegenerating environments of stable wage employment, which appear as a short-lived historical exception. They now resemble the fragmented experiences that have been ubiquitous in the so-called 'third world/global South' for a long time and recall the thwarted 'expectations of modernity' of development ideologies (Breman \& van der Linden 2014; Ferguson 1999). On the one hand, supply-side models of the economy have guided policy towards the degradation of waged labour protection, resulting in an expansion in temporary and part-time jobs and in flexiblework. On the other hand, selfemployment and petty entrepreneurialism as recourses against the failing of secure wage employment opportunities have been actively promoted as a way to enhance individual autonomy and escape the shame of depending on state benefits. The expansion of precarious labour (including self-employment and petty entrepreneurship) has political consequences for the forms of vertical or horizontal solidarity that are more likely to develop and for what the objectives of a labour struggle would be. It revisits the issue of whether different experiences of work invalidate the commonality oflabour (both as a concept andas a position in practice) in its relation to capital, as Guy Standing's (2014) concept of the 'precariat' would have it (for a critique, see Breman 2013; Palmer 2014).

If labour has been understood in the social sciences as directly or indirectly involved in capital accumulation, then what happens to labour as a conceptual tool when increasing numbers of people are described as functionally unnecessary, absolute surplus labour: that is, useless in any form to capital? The question is whether their disconnection from capital is absolute and permanent or rather a concrete expression of labour's relational aspect to the dynamics of capital accumulation in time and space as a response to the spatial, technological, product and financial 'fixes' that define the strategies of capital in its engagement with labour (Silver 2003; 2014). If, indeed, people's diverse strategies to survive, to earn a livelihood by pooling or, on the contrary, by excluding others from encroaching on scarce resources, are entirely disconnected from the social reproduction of a capitalist system, then how are these toils to be conceptually addressed?

Michael Burawoy (2010) has proposed a renewed Polanyian perspective that attempts to bridge conceptual fragmentation by tying labour to money and nature. Here, what become relevant are the situated processes of (re-/de-)commodification of labour in its articulation with these other fictitious commodities. A move from emphasizing 
labour/capital relations in production to stressing the commodity aspect would enable people to forge linkages beyond labour but within capitalist relations. Burawoy's model 'centers on the commodification of labor, money and nature and their interrelations. The argument is premised on commodification being the key experience in our world today, and that exploitation, while essential to any analysís of capitalism, is not experienced as such' (2010: 307, original emphasis). Commodification, then, would bring together the myriad experiences of dispossession and could eventually produce commonality.

\section{Conclusion}

For most people in the world, what we witness is the entanglement of many forms of work, multiple kinds of social relations, institutional involvement in regulation and deregulation, the mobilization of vertical and horizontal solidarities to access resources, and the encroachment of commodification in everyday life. There is nothing inevitable about these circumstances, which are the result of political economic decisions. Indeed, after a period of extreme free-trade policy models (with their obvious caveats of monopoly protection in practice), we may be witnessing the dawn of a protectionist trend that will transform global markets. The predatory nature of unbridled neoliberal capitalism has also generated a return to forms of stewardship of or integration with nature that are curtailing extractive capitalism and supporting alternative subsistence practices (Edelman 2005; Escobar 2008). These processes are complex, and often conservation policies can have negative consequences for local people, depriving them of their access to protected resources they relied on for subsistence (Campbell, this volume; Fairhead, Leach \& Scoones 2012; West 2005). Ethnographies, in any case, point to the end of secure gainful labour as an expectation of a developed economy, and to the anxieties and strategies that this unforeseen reality produces. In a world with a shrinking labour market, work takes on a meaning increasingly removed from a material productivist aspect and linked instead to the self-realization and recognition value aspects (Fraser 2001). For many people living in a state of permanent or cyclical unemployment, the value of work is very centrally its social aspect: being someone is tied to doing something that is recognized in some way as part of what society values (Joshi 2009; Narotzky \& Besnier 2014). Many 'Activation Works' organized by the state, such as that described by Jan Grill in this volume, or volunteer work framed by religious, union, or community associations, such as what Andrea Muehlebach (2012) describes for Northern Italy, become work substitutes that provide a form of worth that remains tied to labour identities.

In this conjuncture of alleged surplus population (i.e.surplus in relation to the ability or willingness of capital to put it to use in the valorization process), how should we reconceptualize labour? Robert Castel (2013) argues that in France non-labour (horstravail) situations remain inscribed in identities that refer to labour, to the paradigm of Fordist, stable, gainful, and socially dignifying experience. Even when absent, labour would maintain the position of core signifier of social value, marking individual self-reliance, productivism, the moral critique of idleness, and free co-operation as the ideological backbone of society. But is this true everywhere? Experiments with alternative forms of provisioning and new value frameworks are transforming the field of possibilities open to populations (including youth in Western Europe, indigenous groups, outcasts, etc.) pushed to the zones of abandonment by the relation between capital and the state. Depending on the remaining connections between these practices 
and the process of self-expansion of the money form of value, I would argue, some of these activities may still provide for the reproduction of labour and hence be related to capital, even when fully embedded in anti- or non-capitalist value domains.

Is a concept of labour useful or even possible as an analytical tool for anthropologists? While capitalism remains hegemonic, I suggest that we do not abandon the concept of labour, as it addresses the connection of people and places in a process that overpowers their will to make a life worth living and abducts them into the aim of the expansion of money value. Even when unpaid and hidden forms of labour may be on the rise, such as neo-bondage, contract farming, or self-employment, these unwaged workers are crucial to capitalist social reproduction. Moreover, the ways in which they become valuable for capital accumulation include their configuration as consumers of commodities, rent, and interest providers.

What minimal content, then, should an anthropologically useful concept of labour propose? First, I suggest that labour as a concept should be restricted to work effort (human energy expenditure) in its relation to capital, taking into account, however, that this relation has many forms, including many non-commodified and unwaged forms which can be dominant in certain historical conjunctures (Narotzky 2016). Second, the concrete/abstract distinction should be maintained as the key to understanding what makes difference valuable as an asset for the valorization of life and of capital. Third, within the concrete aspect of labour (and capital), ambiguity needs to be present. And finally, dislocation, the process of permanently disrupting and reorganizing the spatial-temporal dimensions of everyday life, is a crucial element in the determination of power geometries between labour and capital. Anthropologists have the capacity to interrogate the concept of labour from their immediate ethnographic experience, a situation which opens the way to innumerable theoretical breakthroughs and practical avenues for transforming society. But this must be realized through the tension between concrete experience and theoretical abstraction.

\section{ACKNOWLEDG EMENTS}

Research and writing were funded by the European Research Council Advanced Grant 'Grassroots Economics: Meaning, Project and Practice in the Pursuit of Livelihood' [GRECO], IDEAS-ERC FP7, Project Number 323743. I am grateful to Penny Harvey and to Christian Krohn-Hansen for inviting meto participate in this special issue, and to the anonymous reviewer, whose comments, which helped me clarify sorne points.

REFERENCES

Allinson, J.C. \& A. Anievas 2009. The uses andmisuses of uneven and combined development: an anatomy of a concept. Cambridge Review of International Affairs 22, 4767.

Axelos, K. 1976. Alienation, praxis, and techne in the thought of Karl Marx. Austin: University of Texas Press.

Beynon, H., R. Hudson \& D. Sadler 1994. A place called Teesside: a locality in a global economy. Edinburgh: University Press.

Breman, J. 1976a. A dualistic labour system? A critique of the 'informal sector' concept: I: the informal sector. Economic and Political Weekly 11, 1870-6. 1976b. A dualistic labour system? A critique of the 'informal sector' concept: II: a fragmented labour market. Economic and Political Weekly 11, 1905-8. 1976c. A dualistic labour system? A critique of the 'informal sector' concept: III: labour force and class formation. Economic and Political Weekly 11, 1939-44. 2013. A bogus concept? New Left Review 84, 130-8.

\& M. van der Linden 2014. Informalizing the economy: the return of the social question at a global level. Development and Change 45, 920-40.

Burawoy, M. 2010. From Polanyi to Pollyanna: the false optimism of global labor studies. 
Global Labour Journal 1, 301-13.

Castel, R. 2013. La mont'ee des incertitudes: travail, protections, statut de l'individu. Paris: Seuil. Cole, J. 2014. Producing value among Malagasy marriage migrants in France: managing horizons of expectation. Current Anthropology 55: S9, S85-94.

Collins, J.L. 2016. Expanding the labor theory of value. Dialectical Anthropology 40, 103-23.

Dalla Costa, M.\&S. James 1972. The power ofwomen and the subversion of the community. Frome, Somerset: FallingWall Press.

Duby, G. 1980. The three orders: feudal society imagined (trans. A. Goldhammer). Chicago: University Press.

Edelman, M. 2005. Bringing the moral economy back in ... to the study of 21st-century transnational peasant movements. American Anthropologist 107, 331-45.

Elson, D. 1979. Value: the representation of labour in capitalism. London: CSE Books Humanities Press.

Escobar, A. 2008. Territories of difference: place, movements, life, redes. Durham, N.C.: Duke University Press.

Fairhead, J., M. Leach\&I. Scoones 2012.Green grabbing: a new appropriation of nature? Journal of Peasant Studies 39, 237-61.

Ferguson, J. 1999. Expectations of modernity: myths and meanings of urban life on the Zambian Copperbelt. Berkeley: University of California Press.

2009. Global disconnect: abjection and the aftermath of modernism. In Industrial works and life: an anthropological reader (eds) M. Mollona, G. de Neve \& J. Parry, 311-29. Oxford: Berg.

2013. Declarations of dependence: labour, personhood, and welfare in southern Africa. Journal of the Royal Anthropological Institute (N.S.) 19, 223-42.

Fraser, N. 2001. Recognition without ethics? Theory, Culture \& Society 18: 2-3, 21-42.

Frayss' e, O. 2014. Work and labour as metonymy and metaphor. tripleC 12: 2, 468-85 (available on-line: http://www.triple-c.at/index.php/tripleC/article/view/546, accessed 8 January 2018).

Gill, L. \& S. Kasmir 2016. History, politics, space, labor: on unevenness as an anthropological concept. Dialectical Anthropology 40: 2, 87-102.

Glick Schiller, N. \& A. C, a glar 2009. Towards a comparative theory of locality in migration studies: migrant incorporation and city scale. Journal of Ethic and Migration Studies 35, 177-202.

González de la Rocha, M. 2001. From the resources of poverty to the poverty of resources? The erosion of a survival model. Latin American Perspectives 28: 4, 72-100.

Gudeman, S. \& A. Rivera 1990. Conversations in Colombia: the domestic economy in life and text. Cambridge: University Press.

Gurevich, A.J. 1985. Categories of medieval culture. London: Routledge \& Kegan Paul.

Harvey, D. 1990. The condition of postmodernity. Oxford: Blackwell.

2003. The new imperialism. Oxford: University Press.

Hochschild, A.R. 2003 [1983]. The managed heart: commercialization of human feeling. Berkeley: University of California Press.

Joshi, C. 2009. Despair: the decline of the Kanpur textile mills. In Industrial works and life: an anthropological reader (eds) M. Mollona, G. de Neeve \& J. Parry, 331-9. Oxford: Berg.

Kasmir, S. \& A. Carbonella 2008. Dispossession and the anthropology of labor. Critique of Anthropology 28: 1, 5-25.

Lakoff, G. \& M. Johnson 1980.Metaphors we live by. Chicago: University Press.

Lawson, V. 2007. Geographies of care and responsibility. Annals of the Association of American Geographers 97, 1-11.

Le Goff, J. 1980. Time, work, and culture in the Middle Ages (trans. A. Goldhammer). Chicago: University Press.

Li, T.M. 2009. Tomake live or let die? Rural dispossession and the protection of surplus populations. Antipode 41: S1, 66-93.

2014. Land's end: capitalist relations on an indigenous frontier. Durham, N.C.: Duke University Press.

Locke, J. 1986 [1689]. The second treatise on civil government. Amherst, Mass.: Prometheus.

Malinowski, B. 1978 [1935]. Coral gardens and their magic: a study of the methods of tilling the soil and of agricultural rites in the Trobriand Islands. New York: Dover. 
Marx, K. 1959 [1844]. Economic and philosophic manuscripts of 1844. Moscow: Progress Publishers (available on-line: https://www.marxists.org/archive/marx/works/download/pdf/Economic-Philosophic-Manuscripts1844.pdf, accessed 8 January 2018).

1969 [1845]. Theses on Feuerbach. In Marx/Engels selected works, vol. 1, 13-15.

Moscow: Progress Publishers (available on-line:

https://www.marxists.org/archive/marx/works/1845/theses/theses.htm,

accessed 8 January 2018).

Mingione, E. 1991. Fragmented societies: a sociology of economic life beyond the market paradigm. Oxford: Blackwell.

Moberg, M. 2014. Certification and neoliberal governance: moral economies of Fair Trade in the eastern Caribbean. American Anthropologist 116, 8-22.

Muehlebach, A. 2012. The moral neoliberal: welfare and citizenship in Italy. Chicago: University Press.

Narotzky, S. 2016. Where have all the peasants gone? Annual Review of Anthropology 45, 301-18. S9, 4-16.

\& N. Besnier 2014. Crisis, value, hope: rethinking the economy. Current Anthropology 55:

Nelson, J.A. 2006. Economics for humans. Chicago: University Press.

Nun, J. 1969. Superpoblación relativa, ejército industrial de reserva y masa marginal. Revista Latinoamericana de Sociología 5, 178-236.

Pahl, R.E. 1985. Divisions of labour. Oxford: Blackwell.

Palmer, B.D. 2014. Reconsiderations of class: precariousness as proletarianization. Socialist Register 50, 40-62.

Peattie, L.R. 1980. Anthropological perspectives on the concepts of dualism, the informal sector, and marginality in developing urban economies. International Regional Science Review 5, 1-31.

15, 851-60.

Peck, J. 2002. Political economies of scale: fast policy, interscalar relations, and neoliberal workfare. Economic Geography 78, 331-60.

Pine, F. 2014.Migration as hope: space, time, and imagining the future. Current Anthropology 55: S9, S95-104.

Polanyi, K. 1957. The economy as instituted process. In Trade and market in the early empires: economies in history and theory (eds) K. Polanyi, C. Arensberg\&H. Pearson, 243-69. New York: Free Press.

1971 [1944]. The great transformation. Boston: Beacon.

Portes, A. \& S. Sassen-Koob 1987.Making it underground: comparative material on the informal sector in Western market economies. American Journal of Sociology 93, 30-61.

Quijano Obregón, A. 1974. The marginal pole of the economy and the marginalized labour force. Economy and Society 3, 393-428.

Rosenberg, J. 2006. Why is there no international historical sociology? European Journal of International Relations 12, 307-40.

Scoones, I. 1998. Sustainable rural livelihoods: a framework for analysis. IDS Working Paper 72.

Silver, B. 2003. Forces of labor: workers' movements and globalization since 1870. Cambridge: University Press.

2014. Theorizing the working class in twenty-first-century capitalism. In Workers and labour in a globalised capitalism: contemporary themes and theoretical issues (ed.) M. Atzeni, 4669. London: Palgrave Macmillan.

Smith, G. 2011. Selective hegemony and beyond - populations with 'no productive function': a framework for enquiry. Identities 18, 2-38.

Standing, G. 2014. The precariat: the new dangerous class (Revised edition). London: Bloomsbury Academic.

Strathern, M. 1988. The gender of the gift: problems with women and problems with society in Melanesia. Berkeley: University of California Press.

Weeks, J. 1971. Does employment matter? Manpower and Unemployment Research in Africa 4: 1, 67-70.

West, P. 2005. Translation, value, and space: theorizing an ethnographic and engaged environmental anthropology. American Anthropologist 107, 632-42. 
